\title{
Interview with Jonathan Cohen: Beginning the Legacy of SLOVO Journal
}

\author{
Director of CONCILIATION RESOURCES, JONATHAN COHEN, IN CONVERSATION WiTH SLOVO'S \\ EXECUTIVE EDITOR BORIMIR TOTEV.
}

Jonathan Cohen joined Conciliation Resources in December 1997 and developed the Caucasus programme. In September 2008, he became Director of Programmes overseeing all Conciliation Resources' regional programmes and was appointed Executive Director in May 2016. Previously he was deputy director of the Foundation on Inter-Ethnic Relations in The Hague, working with the OSCE High Commissioner on National Minorities. Before that he worked for International Alert and the Peace Research Institute Oslo. He has been a board member of the DFID/CAF Partnerships in the Non-Profit Sector Programme for Russia; acted as a consultant to United Nations Volunteers, the Heinrich Boell Foundation, the Berghof Foundation and taught at the London School of Economics.

\section{What was THE ENVIRONMENT LIKE at THE School of Slavonic and East European Studies DURING YOUR TIME THERE?}

I studied at the School of Slavonic and East European Studies (SSEES) for two academic years, from 1986 to 1988. During my first year I did a Russian language immersion course, and at the same time sat in on a class in the Master's programme that Prof. Robert Service taught on the Russian Revolution. There was an endless stream of visitors to the School, so I went to all sorts of seminars. It was a very exciting time, coinciding with the early phase of Glasnost and Perestroika. The students doing the Master's programme were quite a small and nuclear group, and I was in between them, as I wasn't an undergraduate doing the language course and nothing else. I got to know the graduate students, because I was doing the language course and also auditing some of the graduate programme.

In my second year, I did the area studies Master's in Russian and Eastern European History and Politics. The programme included three courses: one with Prof. Robert Service on the Russian Revolution, one with Martin McCauley on Soviet Politics, and one with György Schöpflin on East European Political Institutions. In those days SSEES was split between Senate House and Russell Square, and it was a very dynamic time to be there, as the world was changing, with the Soviet Union undergoing what became its death throws, although we didn't know it at the time. There were endless debates about what was happening, what were the implications, people were beginning to be able to get into archives in a way they hadn't previously. 
I remember there were a couple of fascinating conferences with Russian scholars from the Academy of Science in Moscow coming over and having very interesting debates about Soviet history. Giants in the field would come through for ad hoc seminars. Martin McCauley for example, who I did the Soviet Politics course with, would bring in people to do special sessions every few weeks. Alec Nove came and did a session. Mary Dejevsky, who was the Times correspondent in Moscow at the time also came through.

There have been waves and cycles since then, there have been endless fascinating historical moments, you could have pitched up at SSEES at any time and you would have been on the cusp of an interesting moment. Perhaps never as dynamic as in the early days of Glasnost and Perestroika - a worldchanging period. I remember coming back for a seminar in December 1988 and an earthquake had just hit Armenia. Somebody came in and said, “There's been an earthquake in Armenia!” So much was happening and if felt like we were watching history in the making. György Schöpflin, Robert Service and Martin McCauley were fantastic tutors, they really gave time to the students. We were in small groups, being able to get real quality time with our tutors. I didn't do a course with Geoffrey Hosking, but luckily got to know him too.

\section{COULD YOU SENSE THE ‘CRACKS IN THE WALL’ DURING THAT PERIOD OF CHANGE?}

No one had a premonition. When I left SSEES things were still more ordered, not having had the First Congress yet at that point, which happened in 1989 and really showed the fluidity of the situation. I can't remember thinking the Soviet Union is going to collapse, but there was a real sense of uncertainty. I remember the intellectual rigour of the Soviet Press Study Group, which you could go along to at lunchtimes and really witness people bringing their diverse expertise of different issues to the table.

\section{HOW WAS THE IDEA OF SLOVO CONCEIVED?}

SLOVO came about because it was an exciting time and as Masters students people were wanting to speak out. We were all very impressed by the three big journals of the time: Slavonic and East European Review, Slavic Review, and Soviet Studies. The Slavonic and East European Review came from SSEES, but its focus was more on literature, culture, and history, as opposed to politics. As a group of students, we thought we have something to say, or that we'd like to get things out a bit quicker. I had two friends who were doing the Masters programme: Susan Viets and Sabina McGarrahan, and it was their idea to get this going. I decided to chip in and help.

C School of Slavonic and East European Studies, University College London, 2017. 
Geoffrey Hosking did a great piece on popular movements in the first issue, while Julian Graffy did a piece on cinema. One or two students wrote pieces and book reviews too. Susan stayed around for a bit longer, Sabina was there for only one year. Susan and I kept SLOVO going, then Susan went off to Budapest with the Guardian, later going with the Independent in Kyiv. After my two years at SSEES, I myself went to Oxford and carried on editing SLOVO for at least another year from there. That was a lot of work, doing it largely on my own until Mark Galeotti and a couple of others took over. Eventually it was much better that it remained rooted within students at SSEES, as we had tried to make it a SSEES-Oxford collaboration, but it didn't quite work.

The School was great in supporting the idea. Pat Brown (Archie Brown's wife - a great Sovietologist at St. Anthony's College, Oxford) was the Editorial Secretary of the Slavonic and East European Review, and was of fantastic help in giving ideas on how to manage a journal. Michael Brach, who was Director of SSEES at the time, gave us some financial support to get it going. Julian Graffy and John Channon, who were lecturers at SSEES, were the main contacts and were on the Editorial Board, but really it was a question of us coming up with ideas, and them giving us the go-ahead. Lots of the tutors would write short pieces and book reviews. PhD and Masters students would do the same. The School gave us access to the office of the Slavonic and East European Review, where we could store things, work, edit, and the like.

\section{HOW DID YOU CHOOSE THE NAME SLOVO?}

'Slovo' means word, and it resonated in lots of Slavic languages. It just seemed like a nice, easy, short, and snappy name. Originally, we sold it for two pounds, then two pounds fifty. It was crazy, I remember spending one week writing hundreds of letters to libraries, as this was before the internet, so in order to get subscriptions I had to write to places all over the world. It was really exciting when suddenly you'd get an order in from a library in Germany, America, or Australia - which we did! This is where the School was fantastic, because before we had any resources, we were allocated money to send the first issue out to all sorts of institutions and to get them interested. I don't think we were ever self-financing, but we used to bring in a few hundred pounds in terms of subscriptions, and we got to the point when we were paying a chunk of the cost of the printing. We would design it ourselves, take it to the printers around the corner, keeping everything very self-managed. 


\section{HOW MUCH ATTENTION DID SLOVO ATTRACT DURING ITS FIRST YEARS?}

I can't say it was an earth-shattering publication! But we did receive enquiries and subscriptions, and people did want to write articles and review books. One of the trickiest experiences was when I was in Oxford in 1988-89. I got to know a Soros Fellow called Zsolt Németh, who was a member of Fidesz, which at that time had been founded in Hungary as a group of young dynamic individuals, who wanted to overturn the system. Zsolt was in Oxford for a year, and I remember that he wrote a long piece for SLOVO, which was essentially a political manifesto for Fidesz. I remember spending a long time editing it with him, and ultimately reaching the conclusion that it was not the sort of thing we should publish. I was cautious, partly I suppose, because I didn't think SSEES should be publishing political manifestos. Maybe we should have published it. In hindsight, of course we should have published it. It was a dynamic statement. It's interesting to see how Fidesz has evolved, and sad that some of those involved have now turned on the Central European University, an institution that in many ways inherited the intellectual traditions of a place like SSEES.

\section{COULD YOU SHARE SOME INTERESTING CONNECTIONS THAT CAME ABOUT BECAUSE OF SLOVO?}

I went to Moscow for a year in 1991 to do research. Julian Graffy, who as I mentioned had been a great supporter of SLOVO, introduced me to a filmmaker called Evgeniy (Zhenya) Tsymbal, who he had met when he had been a student in the Soviet Union in the 70s. Zhenya went on to make one of the most powerful films of the Glasnost era, Defence Counsel Sedov', which became Russia's only ever BAFTA-awardwinning film. Phil Cavendish, who now teaches at SSEES, and I were students in Moscow together and through Julian we met Zhenya who, took us to the Mosfilm studios and showed us his latest film.

I moved from SSEES to Oxford where I did a further research degree, but I didn't go on to become an academic, although for a long time I stayed focused on the former Soviet Union, particularly the Caucasus. By switching my gaze from Russia to the Caucasus, I moved a little bit out of the immediate reach of SSEES. There was more of a focus on the Caucasus at the School of Oriental and African Studies, but academics at SSEES, like Pete Duncan, were generous in sharing their expertise and I did come back to give talks at SSEES occasionally on our work in the Caucasus.

I would regularly be at SSEES or Chatham House to understand Russia's role in the Cauasus. One of the things that we did at Conciliation Resources, back in 2000-01, was to set up an international relations summer school in Abkhazia. This was for students from throughout the Caucasus. We'd bring together, in 
Abkhazia, about ten Abkhaz, five Georgians, half a dozen Armenians and Azerbaijanis, half a dozen North Caucasians, a couple of Russians, and then five or six students from the United States and Western or Central Europe. The summer school would run for two weeks. To get the Georgians in took an awful lot of negotiating at a time when relations were not good across the Georgian-Abkhaz divide. They aren't good now, the lack of a resolution is very much an ongoing factor. We used to have to negotiate with the Georgian government to get permission for Georgians to enter Abkhazia, and with the Abkhaz authorities to provide protection for the Georgian students. It was rare to get Georgians into Abkhazia as part of structured processes. We would also aim on bringing some internally displaced people - people whose families had been displaced form Abkhazia as a result of the war. During one of the first summer schools Bob Service came and taught for two weeks, and it was fantastic, they all loved Bob! He was at St. Anthony's by then, but it was because of my connection with him at SSEES, that I managed to get him on board. Likewise, with Peter Rutland, who I had met at SSEEES, who was teaching in the United States, but came as lead tutor one summer. Despite being in a different professional world, the contacts I made at SSEES definitely fed into the work I did.

\section{WHAT ADVICE CAN YOU GIVE THOSE OF OUR READERS, WHO MAY BE INTERESTED IN ENTERING THE FIELD?}

While I was a graduate student, in addition to my research and spending a year in Moscow, I made a radio programme for the World Service, was lucky enough to do some work at the Financial Times office in Moscow for the correspondent John Lloyd, and supported an oral history research project in Russia with one of the pioneers of oral history research, Paul Thompson. In the early 1990s I went to work for International Alert, a non-governmental organisation, which was trying to respond to the conflicts and wars that were erupting in the former Soviet Union. My work particularly focused on the Caucasus, initially the North Caucasus, but then more and more on the South Caucasus and for a long time I was deeply involved in the Georgian-Abkhaz conflict and efforts to promote a peace process and to support civic actors to engage. I also worked on Nagorno-Karabakh, as well as for the OSCE High Commission on National Minorities in Crimea and Central Asia. After more than fifteen years focussing on the former Soviet Union (ten years at Conciliation Resources), I began to take on a more global role within Conciliation Resources, overseeing work we were engaged in in conflict regions around the world. Having been at the organisation for twenty years I became Director last year. It has been an interesting transition for me, from someone who tried to develop a specialised focus on what was the Soviet Union, to someone working around the world. 
When I was involved with Soviet studies there was a debate around the degree to which Soviet studies should be seen as something sui generis, or whether it was part of the broader area studies discipline. Perhaps the two don't contradict each other, but I'm a great believer in area studies. When I now look at how Conciliation Resources works in a dozen different conflict regions around the world, I recognize that in order to be able to work in places like South Sudan, Colombia, Central African Republic, Nigeria, Philippines, Papua New Guinea, Kashmir, not to mention the Caucasus, you've really got to understand the context. You've got to know the politics, the history, the dynamics - what makes those societies tick or fail to tick - and this depends upon colleagues who have invested time and effort to understand these societies.

The first thing I'd say to the student readers of SLOVO, is that it is really important to look at your own specialism through the prism of what is happening elsewhere. Being an expert on Russia, or any of the other former Soviet states is fantastic and really important, but to understand the processes of change in those contexts, whether it's the transition to democracy, or it's the entrenchment of authoritarianism never look at them in isolation. One should always try and understand what one can learn from other processes in different countries around the world, because I think that gives you an important comparative framework within which to understand change.

In terms of what we do, it requires detailed knowledge and focussed endeavour to try and support people in countries of conflict to bring about peaceful change. It's challenging, because often this can involve people challenging the systems of power that sustain violence. But is not our job to take sides, rather we look at how the parties in conflicts can be supported to find creative ways out of the impasses that conflicts often arrive at. We work at both a community and political level, supporting people to make peace processes and processes of mediation more effective.

Of course, we need to recruit people to contribute to this work and we have recruited a number of people from SSEES over the years to work in our Caucasus programme. The academic background that comes from a degree at SSEES is important, and it is a foundation on which to build expertise, which also requires time to be spent in context. People with expertise, or the foundations, are those who are attractive to us when posts are open, but I would also suggest that it is important to think beyond a knowledge of the culture and the politics of a given country or region. What are the threats and risks that might impact upon a context around the corner? On top of this we are always asking ourselves whether or not there are comparative lessons that we can draw from the experience of conflicts elsewhere, that can enable us to better respond to the changes in the countries that people at SSEES follow.

I would encourage people at SSEES to follow our newsletter, follow us on Facebook and Twitter. Read what we put out, for instance Accord, which is a journal on peace processes that we publish, and tell us 
what you think of it, tell us if it is providing information and analysis that is useful (keeping in mind that it does not only focus on contexts of direct concern to SSEES). If students and readers of SLOVO are going to spend time in places like the Caucasus, Ukraine, and Central Asia, I'd encourage them to contact NGO's before they go out into these contexts. Establish linkages with people in those societies who are working for change, because they'll often be amongst the most creative and dynamic people who students can learn from and be inspired by. It will help students identify the sorts of work they can engage in after their studies. 